\title{
ANALISIS PENYEBAB KEGAGALAN CHLORINATION PLANT DENGAN METODE FAILURE MODE EFFECT ANALYSIS DAN FAULT TREE ANALYSIS (Studi Kasus di PT PJB UP. GRESIK)
}

\author{
Fitria Retnanti ${ }^{(1)}$, Elly Ismiyah ${ }^{(2)}$, Dzakiyah Widyaningrum ${ }^{(3)}$ \\ Program Studi Teknik Industri, Fakultas Teknik, Universitas Muhammadiyah Gresik \\ Jl. Sumatera No. 101, GKB, Gresik, Jawa Timur 61121 \\ E-mail : arnantyy@gmail.com
}

\begin{abstract}
ABSTRAK
Chlorination Plant adalah suatu alat yang dapat mengelektrolisa air laut dan menghasilkan Sodium Hypochlorite $(\mathrm{NaOCl})$. $\mathrm{NaOCl}$ selanjutnya diinjeksikan ke intake air pendingin condenser, untuk melumpuhkan mikroorganisme laut agar tidak bersarang dan merusak peralatan. Dari data riwayat kerusakan di PT. PJB UP Gresik, ada 180 gangguan selama tahun 2001 - 2018 yang mengakibatkan Chlorination Plant gagal beroperasi. Untuk mencari penyebab dasar dari kegagalan yang dominan, akan dikaji lebih lanjut dengan metode Failure Mode and Effect Analysis dilanjutkan metode Fault Tree Analysis kemudian diberikan usulan pencegahan untuk meminimalkan terjadinya kegagalan pada Chlorination Plant. Dari hasil penelitian diketahui bahwa Rectifier SCR Resistansi Rendah, Cell Chlorine Bocor dan Sea Water Supply Strainer Buntu adalah penyebab kegagalan yang paling dominan. Untuk menurunkan resiko kegagalan, selanjutnya disarankan untuk mereview standart job prediktif maintenance pada peralatan tersebut, sedangkan kegagalan yang diakibatkan karena umur diusulkan untuk memetakan remaining useful life peralatan.
\end{abstract}

Kata kunci : Chlorination Plant, Failure Mode and Effect Analysis , Fault Tree Analysis

\section{PENDAHULUAN}

PT PJB Unit Pembangkitan Gresik merupakan Anak Perusahaan dari PT PLN (Persero) yang bergerak dalam bidang usaha pembangkitan ketenagalistrikan. Disamping mesin-mesin utama yang berupa Unit Pembangkit Listrik, UP Gresik juga mempunyai fasilitas-fasilitas penunjang yang berfungsi untuk mendukung realisasi produk maupun operasional perusahaan, antara lain Chlorination Plant. Chlorination Plant adalah suatu alat yang dapat mengelektrolisa air laut dan menghasilkan Sodium Hypochlorite $(\mathrm{NaOCl})$. $\mathrm{NaOCl}$ selanjutnya diinjeksikan ke intake air pendingin. Pada instalasi pembangkit listrik thermal yang memerlukan air laut untuk pendingin condenser, zat $\mathrm{NaOCl}$ dipakai untuk melumpuhkan mikroorganisme laut agar tidak bersarang dan merusak peralatan.

\subsection{Latar Belakang}

Berdasarkan data operasi di PT PJB UP Gresik didapat sebagai berikut :

1. Kualitas Produk Chlorination Plant berdasarkan data Laporan Mutu air Lokal PLTGU pada bulan Oktober 2018

2. Tanggal 18 - 30 Agustus 2018 sempat terjadi gangguan berupa kebocoran padaCell Chlorine sehingga menyebabkan Chlorination Plant 2 tidak beroperasi, dan mulai beroperasi kembali pada tanggal 31 Agustus 2018

3. Berdasarkan data pemakaian air di Rendal Operasi, pada bulan Juni 2018 pemakaian air pengisi (make up water) mengalami peningkatan bila dibandingkan dengan pemakaian air pada bulan Juni 2017 (data diambil pada saat pembebanan penuh), dikarenakan terjadi kebocoran kondensor akibat kekurangan supply $\mathrm{NaOCl}$ Kekurangan pasokan 
$\mathrm{NaOCl}$ dapat mengganggu pencegahan laju perkembang biakan tumbuhan dan binatang laut baik yang berukuran mikro maupun makro. Gangguan tersebut meliputi :

a. Hambatan pada sistem penukar panas ( sistem pendingin ) kondensor Steam Turbin. b. Terjadinya proses korosi dan kerusakan mekanis pada peralatan pendukung di sistem pendingin Steam Turbin. Berdasarkan data dari bidang rendal niaga apabila terjadi kebocoran atau kerusakan line sistem pendingin yang mengakibatkan kerusakan sistem siklus air laut dan mengakibatkan unit tidak bisa beroperasi 1 jam setara dengan Rp. 40.808.330 kerugian PT PJB UP Gresik apabila tidak beroperasi 1 bulan sebesar Rp 979.399.931.

Pada penelitian ini akan dilakukan analisis menggunakan metode Failure Mode And Effect Analysis kemudian dilanjutkan dengan Fault Tree Analysis untuk mencari penyebab potensial kegagalan Chlorination Plant. Hal itu semua dilakukan untuk meminimalisir kurang efektifnya kinerja Chlorination Plant.

\subsection{Rumusan Masalah}

Berdasarkan latar belakang permasalahan yang ada, maka rumusan masalah yang diambil dalam penulisan penelitian ini adalah sebagai berikut:

\section{TINJAUAN PUSTAKA}

\subsection{Failure Mode and Effect Analysis (FMEA)}

FMEA adalah pendekatan sistematik yang menerapkan suatu metode pentabelan dengan menentukan mode kegagalan, penyebab kegagalan dan efek dari kegagalan hal ini untuk membantu proses pemikiran yang digunakan oleh engineers untuk mengidentifikasi mode kegagalan potensial dan efeknya. FMEA merupakan teknik evaluasi tingkat keandalan dari sebuah sistem untuk menentukan efek dari kegagalan dari sistem tersebut. Kegagalan digolongkan berdasarkan
1. Bagaimana mode kegagalan, penyebab kegagalan dan efek kegagalan pada Chlorination Plant dengan menggunakan metode Failure Mode Effect Analysis.

2. Apakah akar permasalahan dari mode mode kegagalan, yang dapat menyebabkan kegagalan Chlorination Plant dengan menggunakan metode Fault Tree Analysis.

\subsection{Tujuan Penelitian}

Adapun tujuan analisis ini adalah:

1. Mengidentifikasi dan menentukan penyebab kegagalan yang paling dominan pada Chlorination Plant.

2. Mencari penyebab dasar dari kegagalan yang dominan.

3. Mengusulkan pencegahan untuk meminimalkan terjadinya kegagalan pada Chlorination Plant.

\subsection{Manfaat Penelitian}

Adapun manfaat yang dapat diperoleh dari hasil penelitian tugas akhir / skripsi ini antara lain :

1. Mengetahui kegagalan yang paling dominan pada Chlorination Plant.

2. Mengetahui penyebab dasar dari kegagalan yang dominan

3. Mendapatkan usulan pencegahan untuk meminimalkan terjadinya kegagalan pada Chlorination Plant.

dampak yang diberikan terhadap kesuksesan suatu misi dari sebuah sistem.

\subsection{Saverity (Tingkat Keparahan)}

Tingkat keparahan adalah perkiraan subjektif numerik dari seberapa parah pelanggan (pengguna berikutnya) atau pengguna akhir yang akan merasakan EFEK kegagalan. Severity kerusakan pada sistem dibedakan menjadi 10 skala (Blanchard, 2004) dalam Surasa (2007), adapun kategori yang digunakan, sebagai berikut:

1. Skala 1 untuk kerusakan dengan efek minor

2. Skala 2-3 untuk kerusakan dengan efek rendah (low) 
3. Skala 4-6 untuk kerusakan dengan efek sedang (moderate)

4. Skala 7-8 untuk kerusakan dengan efek tinggi (high)

5. Skala 9-10 untuk kerusakan dengan efek sangat tinggi (very high)

2.3 Occurrence (tingkat kemungkinan kejadian) Tingkatan waktu atau kemungkinan terjadinya kadang-kadang disebut, adalah estimasi subjektif numerik dari kemungkinan yang menyebabkan, jika terjadi, akan menghasilkan failure mode dan efek khususnya. Frekuensi terjadinya kerusakan dapat ditentukan berdasarkan periode waktu dan dapat dibedakan menjadi 10 skala Blanchard, 2004) dalam Surasa (2007), kategori skala-skala tersebut, sebagai berikut:

1. Skala 1 untuk kerusakan karena kondisi yang tidak biasa dan jarang sekali terjadi (unlikely)

2. Skala 2-3 untuk kerusakan yang frekuensinya rendah (low)

3. Skala 4-6 untuk kerusakan yang frekuensinya sedang (moderate)

4. Skala 7-8 untuk kerusakan yang frekuensinya tinggi (high)

5. Skala 9-10 untuk kerusakan yang frekuensinya sangat tinggi (very high).

\subsection{Detection (Deteksi)}

Deteksi kadang-kadang disebut efektifitas. Ini adalah perkiraan subjektif numerik efektivitas kontrol untuk mencegah atau mendeteksi penyebab atau failure mode sebelum kegagalan mencapai pelanggan. Asumsinya adalah yang menyebabkan telah terjadi. Kemungkinan pengendalian suatu kerusakan IV- 23dapat dibedakan menjadi 10 skala (Blanchard, 2004) dalam Surasa (2007), kategori skala-skala tersebut sebagai berikut:

1. Skala 1-2 untuk kerusakan yang memiliki peluang pengendalian sangat tinggi (very high).

2. Skala 3-4 untuk kerusakan yang memiliki peluang pengendalian tinggi (high).

3. Skala 5-6 untuk kerusakan yang memiliki peluang pengendalian sedang (moderate).
4. Skala 7-8 untuk kerusakan yang memiliki peluang pengendalian rendah (low).

5. Skala 9 untuk kerusakan yang memiliki peluang pengendalian sangat rendah (very low).

6. Skala 10 untuk kerusakan yang memiliki peluang pengendalian tidak menentu atau bahkan tidak terkendali.

\subsection{Perhitungan Risk Priority Number (RPN)}

Untuk menetukan prioritas dari suatu bentuk kegagalan maka harus terlebih dahulu mendefinisikan tentang Severity, Occurrence, Detection yang hasil akhirnya berupa RPN (Risk Priority Number).Perhitungan RPN (Risk Priority Number) dari hasil FMEA:

\section{$\mathbf{R P N}=\mathbf{S} \times \mathbf{O} \times \mathbf{D}$}

Menyediakan pendekatan evaluasi alternatif untuk Analisis Kekritisan. Jumlah prioritas risiko memberikan perkiraan numerik kualitatif risiko desain. RPN didefinisikan sebagai produk dari tiga faktor independen dinilai :

- $\quad S=$ Saverity (tingkat keparahan)

- $O=$ Occurrence (tingkat kejadian)

- $\quad D=$ Detection (Deteksi).

Risk Priority Number (RPN) adalah ukuran yang digunakan ketika menilai risiko untuk membantu mengidentifikasi "critical failure modes" terkait dengan desain atau proses. Nilai RPN berkisar dari 1 (terbaik mutlak) hingga 1000 (absolut terburuk). RPN FMEA adalah umum digunakan dalam industri dan agak mirip dengan nomor kekritisan yang digunakan.

\subsection{Fault Tree Analysis (FTA)}

Fault Tree Analysis (FTA) adalah salah satu contoh metode analisis proses yang digunakan dalam pencarian suatu permasalahan dalam suatu proses, dimana terdapat suatu kejadian yang tidak diinginkan disebut undesired event terjadi pada sistem, dan sistem tersebut kemudian dianalisis dengan kondisi lingkungan dan operasional yang ada untuk menemukan semua cara yang mungkin terjadi yang mengarah pada terjadinya undesired 
event tersebut (Vesely dkk, 1981) dalam Ning Puji Lestari, Siti Syamsiah, Sarto dan Wiratni

Budhijanto, 2016. Dengan metode FTA ini, akan dapat diketahui kegagalan-kegagalan yang menjadi penyebab terjadinya undesired event, dan probabilitas terjadinya undesired event tersebut. Untuk menganalisis kegagalan sistem dengan metode FTA, perlu dibuat pohon kegagalan atau fault tree dari sistem yang dianalisis terlebih dahulu. Fault tree adalah model grafis dari kegagalan-kegagalan pada sistem dan kombinasinya yang menghasilkan terjadinya undesired event (Vesely dkk, 1981) dalam Ning Puji Lestari, Siti Syamsiah, Sarto dan Wiratni Budhijanto, 2016. FTA disusun berdasarkan simbol simbol yang berisi keterangan suatu kejadian pada sistem dan gerbang logika untuk menerangkan keterkaitan terhadap suatu kejadian.

\subsection{Fishbone Diagram}

Fishbone diagram akan mengidentifikasi berbagai sebab potensial dari satu efek atau masalah, dan menganalisis masalah tersebut melalui sesi

\section{METODE PENELITIAN}

Dalam mencari solusi dari sebuah penelitian yang diamati tentang kegagalan Chlorination Plant, brainstorming. Masalah akan dipecah menjadi sejumlah kategori yang berkaitan, mencakup manusia, material, mesin, prosedur, kebijakan, dan sebagainya. Setiap kategori mempunyai sebabsebab yang perlu diuraikan melalui sesi brainstorming.

\subsection{Chlorination Plant}

Dalam sebuah pembangkit Thermal air laut berperan besar dalam menunjang proses kerja unit pembangkit listrik yang mengunakan media pendingin air laut. Dimana air laut dimanfaatkan sebagai media pendingin pada Condensor Steam Turbin. Tetapi dalam proses pendinginan dengan media air laut perlu dilakukan injeksi kimia yaitu Zat Chlorine/ sodium hypochloride yang mana Zat ini berguna untuk mencegah berkembang biaknya biota laut (binatang dan tumbuhan laut) agar tidak menempel pada line-line dari sistem pendinginan air laut tersebut dengan cara memabukkannya.

dibutuhkan langkah - langkah untuk menguraikan pendekatan dan model dari masalah tersebut. 


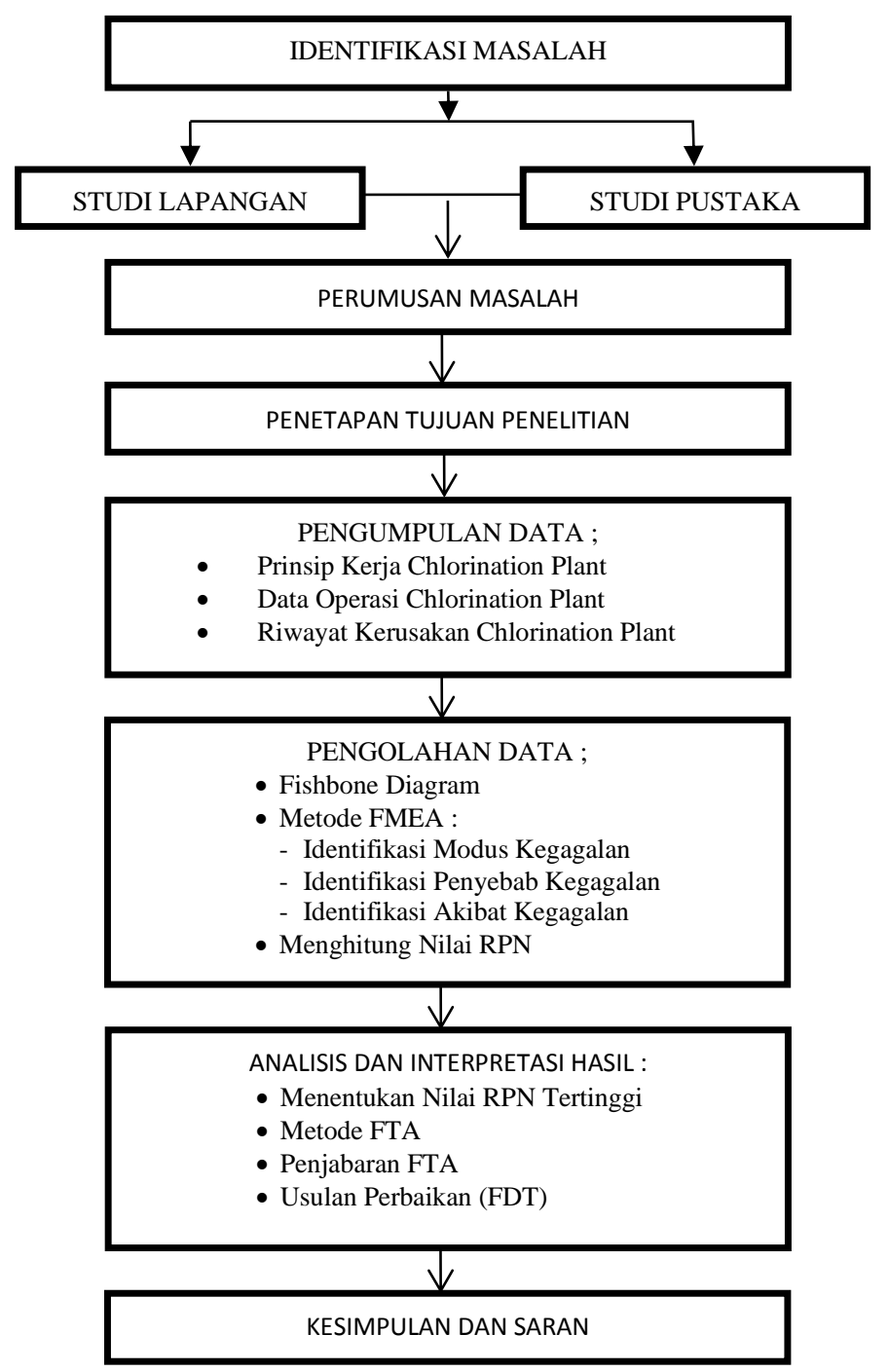

Gambar 3.1 Flow Chart Metodologi Penelitian

\section{PENGUMPULAN DAN PENGOLAHAN DATA}

\subsection{Pengumpulan Data}

Pada tahap ini data yang dikumpulkan ialah data :

1. Prinsip Kerja Chlorination Plant 


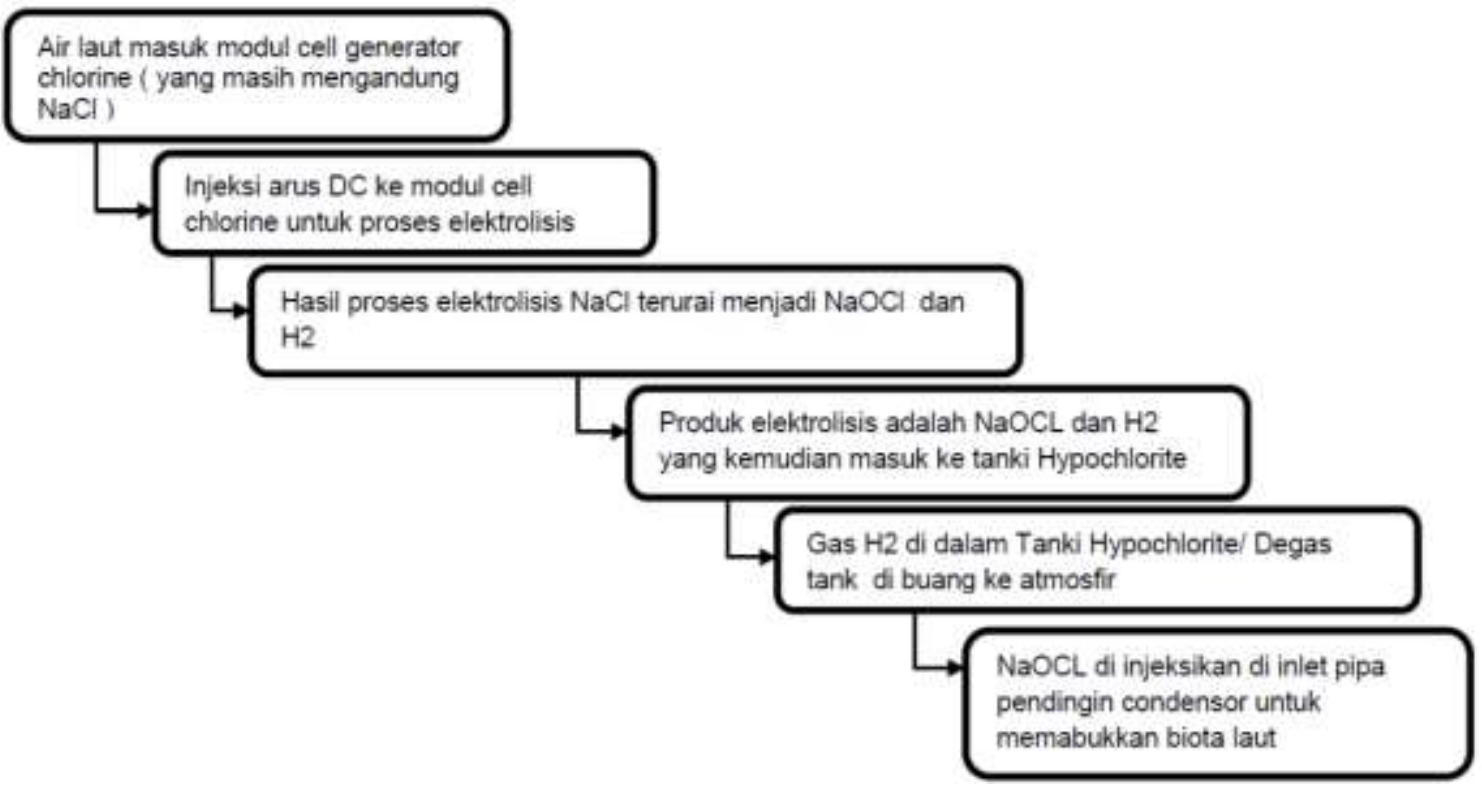

Gambar 3.1 Flow Chart Metodologi Penelitian

\section{Data operasi Chlorination Plant}

Berikutnya adalah data Performance Chlorination Plant Unit 2 :

Tabel 4.1 Data Operasi Chlorination Plant Agustus 2018

\begin{tabular}{|c|c|c|c|c|c|c|}
\hline \multirow[t]{2}{*}{ Tanggat } & FLOW & TEGANGAN & ARUS & JUMLAH & $\mathrm{Cl}_{2}$ & $\mathrm{Cl}_{3}$ \\
\hline & $\left(\mathrm{m}^{3} \mathrm{Thr}\right)$ & (Volt) & (Ampere) & MODUL & (ppm) & $\mathrm{kg} / \mathrm{jam}$ \\
\hline 1 & 86 & 64 & 3000 & 16 & 608 & 52 \\
\hline 2 & 0 & 0 & 0 & 0 & 0 & 0 \\
\hline 3 & 86 & 70 & 3400 & 16 & 788 & 68 \\
\hline 4 & 0 & 0 & 0 & 0 & 0 & 0 \\
\hline 5 & 0 & 0 & 0 & 0 & 0 & 0 \\
\hline 6 & 80 & 68 & 3600 & 16 & 875 & 70 \\
\hline 7 & 0 & 0 & 0 & 0 & 0 & 0 \\
\hline 8 & 68 & 68 & 3400 & 16 & 867 & 59 \\
\hline 9 & 0 & 0 & 0 & 0 & 0 & 0 \\
\hline 10 & 90 & 66 & 3200 & 16 & 865 & 78 \\
\hline 11 & 0 & 0 & 0 & 0 & 0 & 0 \\
\hline 12 & 0 & 0 & 0 & 0 & 0 & 0 \\
\hline 13 & 85 & 68 & 3200 & 16 & 810 & 69 \\
\hline 14 & 0 & 0 & 0 & 0 & 0 & 0 \\
\hline 15 & 76 & 68 & 3400 & 15 & 980 & 75 \\
\hline 16 & 0 & 0 & 0 & 0 & 0 & 0 \\
\hline 17 & 84 & 68 & 3500 & 15 & 645 & 54 \\
\hline 18 & 0 & 0 & 0 & 0 & 0 & 0 \\
\hline 19 & 0 & 0 & 0 & 0 & 0 & 0 \\
\hline 20 & 0 & 0 & 0 & 0 & 0 & 0 \\
\hline 21 & 0 & 0 & 0 & 0 & 0 & 0 \\
\hline 22 & 0 & 0 & 0 & 0 & 0 & 0 \\
\hline 23 & 0 & 0 & $\theta$ & 0 & 0 & 0 \\
\hline 24 & 0 & 0 & 0 & 0 & 0 & 0 \\
\hline 25 & 0 & 0 & 0 & 0 & 0 & 0 \\
\hline 26 & 0 & 0 & $\theta$ & 0 & 0 & 0 \\
\hline 27 & 0 & 0 & 0 & 0 & 0 & 0 \\
\hline 28 & 0 & 0 & 0 & 0 & 0 & 0 \\
\hline 29 & 0 & 0 & 0 & 0 & 0 & 0 \\
\hline 30 & 0 & 0 & 0 & 0 & 0 & 0 \\
\hline 31 & 86 & 68 & 4000 & 18 & 870 & 74 \\
\hline
\end{tabular}


Tabel 4.2 Data Performance Test Chlorination Plant Februari 2010

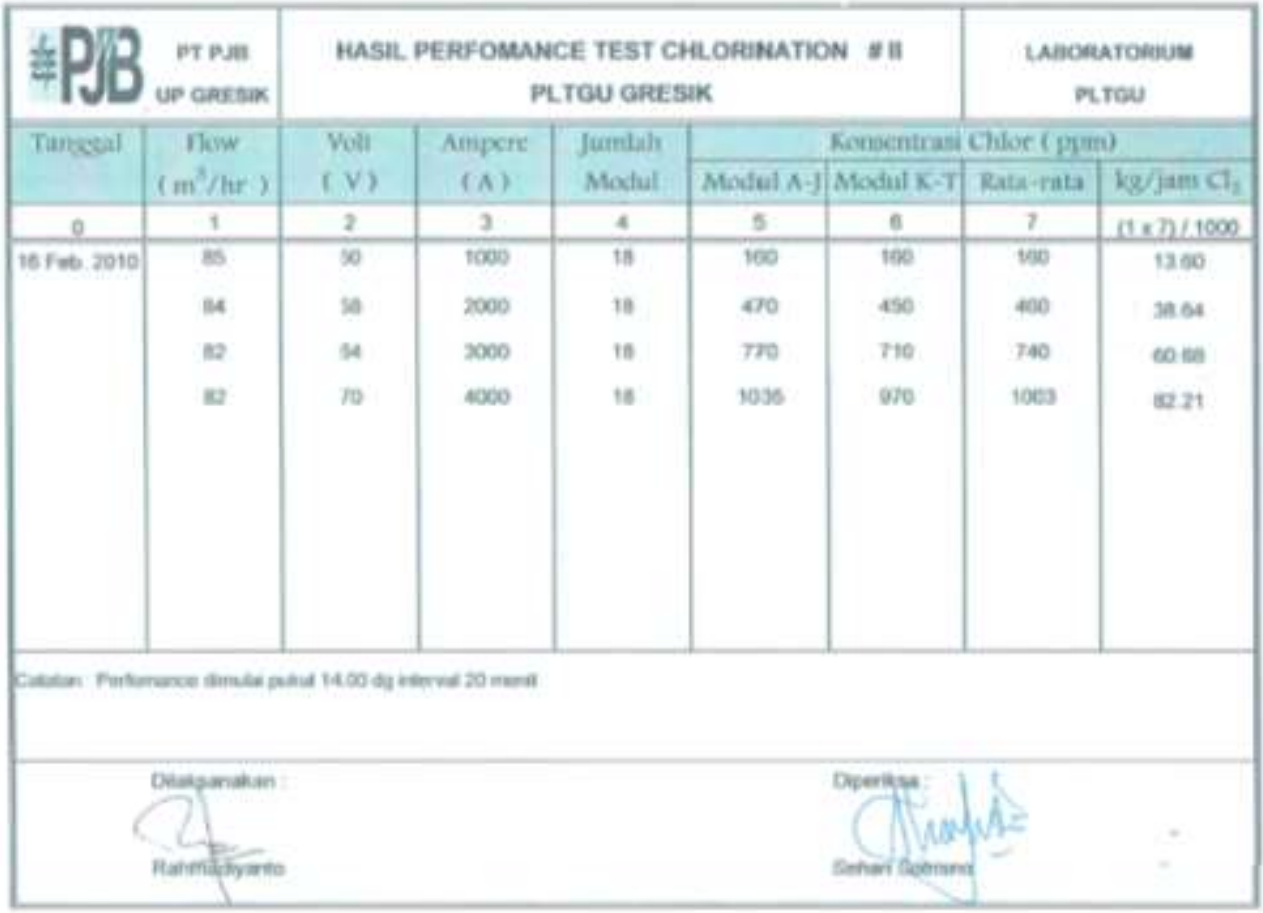

Tabel 4.1 mewakili kondisi operasi chlorination plant saat ini, sedangkan pada tabel 4.2 adalah riwayat operasi unit terdahulu. Dari kedua tabel, terlihat bahwa terjadi penurunan performance unit 2 pada bulan Agustus 2018 bila dibandingkan dengan bulan Februari 2010.

\section{Data Riwayat Kerusakan}

Data riwayat kerusakan alat diambil dari work order (WO). WO didapat dari database program MIM'S ELLIPSE yang diterapkan dan digunakan pada seluruh unit PT PJB. Dari periode 2001 - 2018 didapatkan 183 WO yang berkaitan dengan Chlorination Plant

\subsection{Pengolahan Data}

Dari data operasi dan riwayat kerusakan yang telah didapat kemudian diolah dengan metode yang sudah ditentukan, untuk memahami dan mempermudah menganalisis dari sebuah permasalahan. 


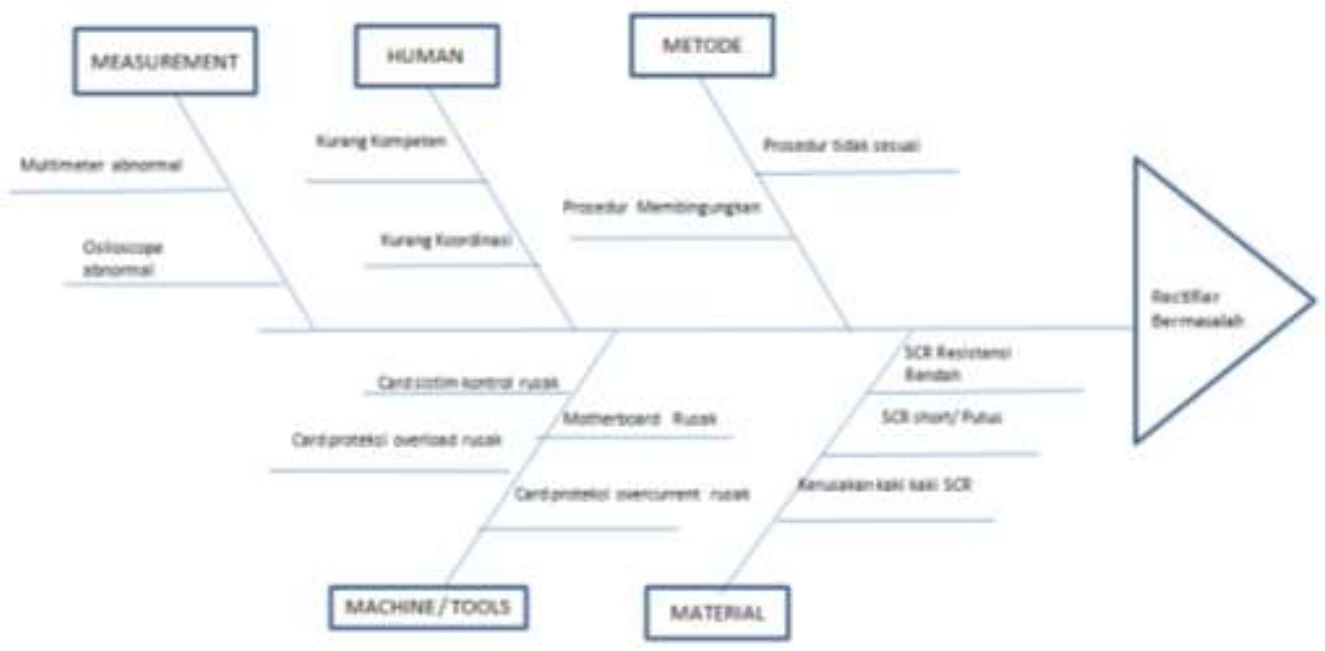

Gambar 4.1 Fishbone Diagram Rectifier

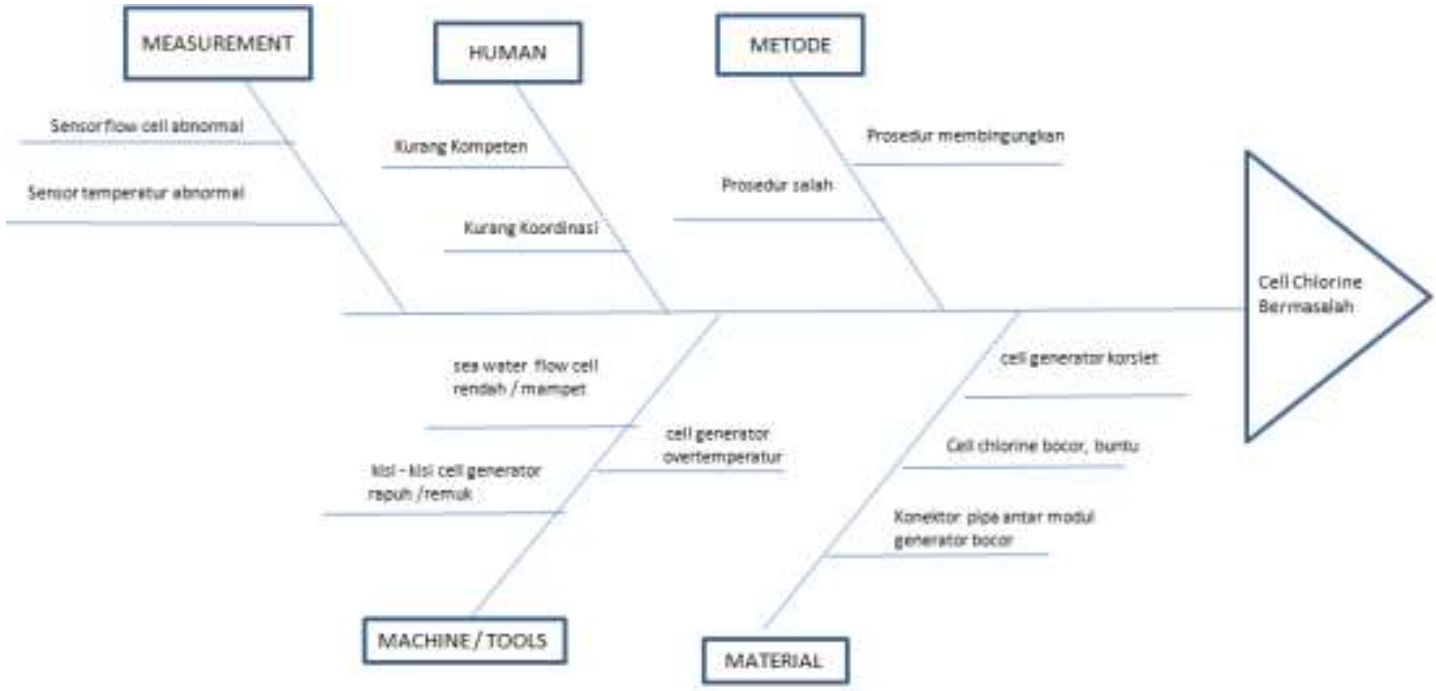

Gambar 4.2 Fishbone Diagram Cell Chlorine 


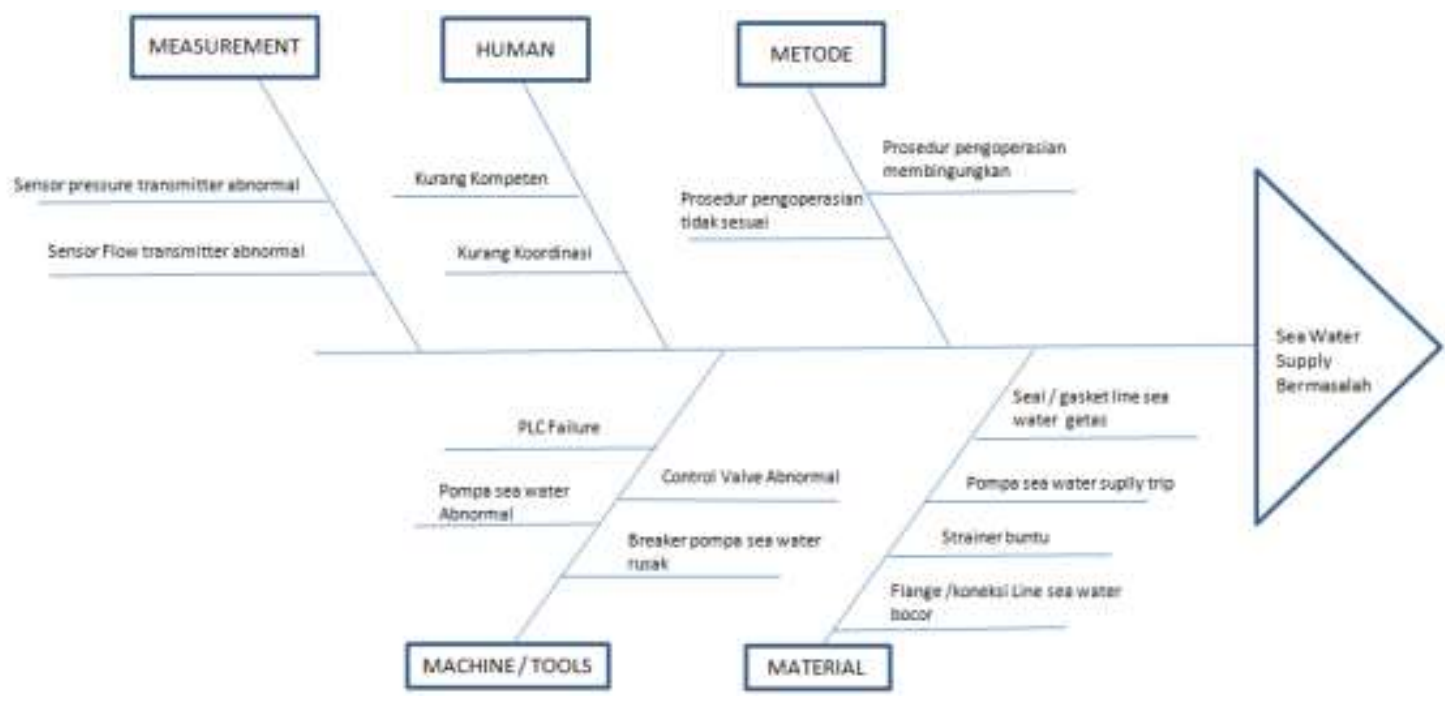

Gambar 4.3 Fishbone Diagram Sea Water Supply

Kemudian dilanjutkan dengan pembuatan tabel FMEA sebagai berikut :

Tabel 4.6 FMEA Kegagalan Operasi Chlorination Plant

\begin{tabular}{|c|c|c|c|c|c|c|c|c|c|}
\hline No. & $\begin{array}{l}\text { Sub } \\
\text { Equipment }\end{array}$ & Category & $\begin{array}{l}\text { Failure } \\
\text { Mode }\end{array}$ & $\begin{array}{l}\text { Failure } \\
\text { Cause }\end{array}$ & $\begin{array}{l}\text { Failure } \\
\text { Effect }\end{array}$ & $\begin{array}{c}\text { Severit } \\
\mathrm{y} \\
(\mathrm{S})\end{array}$ & $\begin{array}{c}\text { Occurren } \\
\text { ce }(\mathrm{O})\end{array}$ & $\begin{array}{c}\text { Detectio } \\
\mathrm{n}(\mathrm{D})\end{array}$ & $\begin{array}{l}\mathrm{RP} \\
\mathrm{N}\end{array}$ \\
\hline \multirow[b]{2}{*}{1} & \multirow{6}{*}{$\begin{array}{c}\text { RECTIFIE } \\
\mathrm{R}\end{array}$} & \multirow[t]{2}{*}{$\begin{array}{c}\text { Measurem } \\
\text { ent }\end{array}$} & $\begin{array}{c}\text { Multimeter } \\
\text { Abnormal }\end{array}$ & $\begin{array}{c}\text { 1. Alat } \\
\text { ukur tidak } \\
\text { terkalibrasi } \\
\text { 2. Probe } \\
\text { terbalik }\end{array}$ & $\begin{array}{c}\text { Rectifier } \\
\text { Bermasalah }\end{array}$ & 2 & 3 & 1 & 6 \\
\hline & & & $\begin{array}{l}\text { Osiloscope } \\
\text { Abnormal }\end{array}$ & $\begin{array}{c}\text { 1. Alat } \\
\text { ukur tidak } \\
\text { terkalibrasi } \\
\text { 2. Probe } \\
\text { terbalik/ } \\
\text { Rusak }\end{array}$ & $\begin{array}{c}\text { Rectifier } \\
\text { Bermasala } \\
\text { h }\end{array}$ & 2 & 3 & 1 & 6 \\
\hline \multirow[b]{2}{*}{2} & & \multirow[b]{2}{*}{ Human } & $\begin{array}{c}\text { Kurang } \\
\text { Kompeten }\end{array}$ & $\begin{array}{l}\text { Operator } \\
\text { tidak } \\
\text { kompeten }\end{array}$ & $\begin{array}{c}\text { Rectifier } \\
\text { Bermasalah }\end{array}$ & 3 & 1 & 2 & 6 \\
\hline & & & $\begin{array}{c}\text { Kurang } \\
\text { Koordinasi }\end{array}$ & $\begin{array}{l}\text { Operator } \\
\text { kurang } \\
\text { koordinasi }\end{array}$ & $\begin{array}{c}\text { Rectifier } \\
\text { Bermasalah }\end{array}$ & 2 & 2 & 2 & 8 \\
\hline \multirow[t]{2}{*}{5} & & Metode & $\begin{array}{c}\text { Prosedur } \\
\text { membingun } \\
\text { g-kan }\end{array}$ & $\begin{array}{c}\text { Prosedur } \\
\text { Tidak Up } \\
\text { to Date }\end{array}$ & $\begin{array}{c}\text { Rectifier } \\
\text { Bermasalah }\end{array}$ & 2 & 2 & 2 & 8 \\
\hline & & & $\begin{array}{l}\text { Prosedur } \\
\text { tidak sesuai }\end{array}$ & $\begin{array}{c}\text { Prosedur } \\
\text { tidak }\end{array}$ & $\begin{array}{c}\text { Rectifier } \\
\text { Bermasalah }\end{array}$ & 2 & 2 & 2 & 8 \\
\hline
\end{tabular}




\begin{tabular}{|c|c|c|c|c|c|c|c|c|c|}
\hline & & & & $\begin{array}{c}\text { terperinci } \\
\text { secara jelas }\end{array}$ & & & & & \\
\hline \multirow{4}{*}{4} & & \multirow{4}{*}{$\begin{array}{c}\text { Machine } \\
\text { Tool }\end{array}$} & $\begin{array}{c}\text { Card sistim } \\
\text { kontrol } \\
\text { rusak }\end{array}$ & $\begin{array}{c}\text { Aging, } \\
\text { lembab / } \\
\text { kotor }\end{array}$ & $\begin{array}{c}\text { Rectifier } \\
\text { Bermasalah }\end{array}$ & 5 & 2 & 1 & 10 \\
\hline & & & $\begin{array}{c}\text { Motherboar } \\
\text { d SCR } \\
\text { Rusak }\end{array}$ & $\begin{array}{l}\text { Aging } \\
\text { lembab / } \\
\text { kotor }\end{array}$ & $\begin{array}{c}\text { Rectifier } \\
\text { Bermasalah }\end{array}$ & 5 & 2 & 1 & 10 \\
\hline & & & $\begin{array}{c}\text { Card } \\
\text { proteksi } \\
\text { overcurrent } \\
\text { rusak }\end{array}$ & $\begin{array}{l}\text { Aging } \\
\text { lembab / } \\
\text { kotor }\end{array}$ & $\begin{array}{c}\text { Rectifier } \\
\text { Bermasalah }\end{array}$ & 5 & 2 & 1 & 10 \\
\hline & & & $\begin{array}{c}\text { Card } \\
\text { proteksi } \\
\text { overload } \\
\text { rusak }\end{array}$ & $\begin{array}{l}\text { Aging, } \\
\text { lembab / } \\
\text { kotor }\end{array}$ & $\begin{array}{c}\text { Rectifier } \\
\text { Bermasalah }\end{array}$ & 5 & 2 & 1 & 10 \\
\hline \multirow{3}{*}{5} & & \multirow{3}{*}{ Material } & $\begin{array}{c}\text { SCR } \\
\text { Resistansi } \\
\text { Rendah }\end{array}$ & Aging & $\begin{array}{c}\text { Rectifier } \\
\text { Bermasalah }\end{array}$ & 5 & 3 & 1 & 15 \\
\hline & & & $\begin{array}{c}\text { SCR short/ } \\
\text { putus }\end{array}$ & Pola beban & $\begin{array}{c}\text { Rectifier } \\
\text { Bermasalah }\end{array}$ & 5 & 2 & 1 & 10 \\
\hline & & & $\begin{array}{c}\text { Kerusakan } \\
\text { kaki kaki } \\
\text { SCR }\end{array}$ & Pola beban & $\begin{array}{c}\text { Rectifier } \\
\text { Bermasalah }\end{array}$ & 5 & 2 & 1 & 10 \\
\hline \multirow{2}{*}{6} & \multirow{6}{*}{$\begin{array}{c}\text { CELL } \\
\text { CHLORIN } \\
\text { E }\end{array}$} & \multirow{2}{*}{$\begin{array}{c}\text { Measurem } \\
\text { ent }\end{array}$} & $\begin{array}{l}\text { Sensor flow } \\
\text { abnormal }\end{array}$ & $\begin{array}{l}\text { kondisi } \\
\text { sensor } \\
\text { tidak } \\
\text { terkalibrasi }\end{array}$ & $\begin{array}{c}\text { Cell } \\
\text { Chlorine } \\
\text { Bermasalah }\end{array}$ & 3 & 2 & 2 & 12 \\
\hline & & & $\begin{array}{c}\text { Sensor } \\
\text { temperatur } \\
\text { abnormal }\end{array}$ & $\begin{array}{c}\text { kondisi } \\
\text { sensor } \\
\text { tidak } \\
\text { terkalibrasi }\end{array}$ & $\begin{array}{c}\text { Cell } \\
\text { Chlorine } \\
\text { Bermasalah }\end{array}$ & 3 & 2 & 2 & 12 \\
\hline \multirow{2}{*}{7} & & \multirow{2}{*}{ Human } & $\begin{array}{c}\text { Kurang } \\
\text { kompeten }\end{array}$ & $\begin{array}{c}\text { kurang } \\
\text { kompeten }\end{array}$ & $\begin{array}{c}\text { Cell } \\
\text { Chlorine } \\
\text { Bermasalah }\end{array}$ & 3 & 1 & 2 & 6 \\
\hline & & & $\begin{array}{c}\text { Kurang } \\
\text { koordinasi }\end{array}$ & $\begin{array}{c}\text { kurang } \\
\text { kompeten }\end{array}$ & $\begin{array}{c}\text { Cell } \\
\text { Chlorine } \\
\text { Bermasalah }\end{array}$ & 3 & 1 & 2 & 6 \\
\hline \multirow[b]{2}{*}{8} & & \multirow[b]{2}{*}{ Metode } & $\begin{array}{c}\text { Prosedur } \\
\text { membingun } \\
\text { gkan }\end{array}$ & $\begin{array}{c}\text { Prosedur } \\
\text { Tidak Up } \\
\text { to Date }\end{array}$ & $\begin{array}{c}\text { Cell } \\
\text { Chlorine } \\
\text { Bermasalah }\end{array}$ & 2 & 2 & 2 & 8 \\
\hline & & & $\begin{array}{l}\text { Prosedur } \\
\text { tidak sesuai }\end{array}$ & $\begin{array}{l}\text { Prosedur } \\
\text { tidak } \\
\text { terperinci } \\
\text { secara jelas }\end{array}$ & $\begin{array}{c}\text { Cell } \\
\text { Chlorine } \\
\text { Bermasalah }\end{array}$ & 2 & 2 & 2 & 8 \\
\hline
\end{tabular}




\begin{tabular}{|c|c|c|c|c|c|c|c|c|c|}
\hline \multirow{3}{*}{9} & & \multirow{3}{*}{$\begin{array}{l}\text { Machine } \\
\text { Tool }\end{array}$} & $\begin{array}{c}\text { Flow sea } \\
\text { water cell } \\
\text { rendah }\end{array}$ & $\begin{array}{l}\text { pengeraka } \\
\mathrm{n} \text { pada cell } \\
\text { generator }\end{array}$ & $\begin{array}{c}\text { Cell } \\
\text { Chlorine } \\
\text { Bermasalah }\end{array}$ & 3 & 3 & 2 & 18 \\
\hline & & & $\begin{array}{l}\text { Kisi-Kisi } \\
\text { cell rapuh / } \\
\text { remuk }\end{array}$ & aging & $\begin{array}{c}\text { Cell } \\
\text { Chlorine } \\
\text { Bermasalah }\end{array}$ & 3 & 2 & 2 & 12 \\
\hline & & & $\begin{array}{c}\text { Cell } \\
\text { generator } \\
\text { over } \\
\text { temperatur }\end{array}$ & cell kotor & $\begin{array}{c}\text { Cell } \\
\text { Chlorine } \\
\text { Bermasalah }\end{array}$ & 4 & 3 & 2 & 24 \\
\hline \multirow{3}{*}{10} & & \multirow{3}{*}{ Material } & $\begin{array}{c}\text { Cell } \\
\text { korsleting }\end{array}$ & $\begin{array}{l}\text { koneksi } \\
\text { terbalik, } \\
\text { terminal } \\
\text { kendor }\end{array}$ & $\begin{array}{c}\text { Cell } \\
\text { Chlorine } \\
\text { Bermasalah }\end{array}$ & 2 & 1 & 1 & 2 \\
\hline & & & Cell bocor & $\begin{array}{l}\text { flange } \\
\text { koneksi } \\
\text { kendor / } \\
\text { gasket } \\
\text { getas }\end{array}$ & $\begin{array}{c}\text { Cell } \\
\text { Chlorine } \\
\text { Bermasalah }\end{array}$ & 4 & 4 & 2 & 32 \\
\hline & & & $\begin{array}{l}\text { Konektor } \\
\text { pipa antar } \\
\text { modul } \\
\text { generator } \\
\text { bocor }\end{array}$ & $\begin{array}{c}\text { flange } \\
\text { koneksi } \\
\text { kendor / } \\
\text { gasket } \\
\text { getas }\end{array}$ & $\begin{array}{c}\text { Cell } \\
\text { Chlorine } \\
\text { Bermasalah }\end{array}$ & 4 & 2 & 1 & 8 \\
\hline \multirow{2}{*}{11} & \multirow{6}{*}{$\begin{array}{c}\text { SEA } \\
\text { WATER } \\
\text { SUPPLY }\end{array}$} & \multirow{2}{*}{$\begin{array}{c}\text { Measurem } \\
\text { ent }\end{array}$} & $\begin{array}{c}\text { Sensor } \\
\text { pressure } \\
\text { transmitter } \\
\text { abnormal }\end{array}$ & $\begin{array}{c}\text { sensor } \\
\text { pressure } \\
\text { transmitter } \\
\text { tidak } \\
\text { terkalibrasi }\end{array}$ & $\begin{array}{l}\text { Sea Water } \\
\text { Supply } \\
\text { Bermasalah }\end{array}$ & 2 & 3 & 1 & 6 \\
\hline & & & $\begin{array}{c}\text { Sensor flow } \\
\text { transmitter } \\
\text { abnormal }\end{array}$ & $\begin{array}{l}\text { sensor } \\
\text { flow } \\
\text { transmitter } \\
\text { tidak } \\
\text { terkalibrasi }\end{array}$ & $\begin{array}{l}\text { Sea Water } \\
\text { Supply } \\
\text { Bermasalah }\end{array}$ & 2 & 3 & 1 & 6 \\
\hline \multirow{2}{*}{12} & & \multirow{2}{*}{ Human } & $\begin{array}{c}\text { Kurang } \\
\text { kompeten }\end{array}$ & $\begin{array}{c}\text { kurang } \\
\text { kompeten }\end{array}$ & $\begin{array}{l}\text { Sea Water } \\
\text { Supply } \\
\text { Bermasalah }\end{array}$ & 3 & 1 & 2 & 6 \\
\hline & & & $\begin{array}{c}\text { Kurang } \\
\text { koordinasi }\end{array}$ & $\begin{array}{c}\text { kurang } \\
\text { kompeten }\end{array}$ & $\begin{array}{l}\text { Sea Water } \\
\text { Supply } \\
\text { Bermasalah }\end{array}$ & 3 & 1 & 2 & 6 \\
\hline \multirow[b]{2}{*}{13} & & \multirow[b]{2}{*}{ Metode } & $\begin{array}{l}\text { Prosedur } \\
\text { membingun } \\
\text { gkan }\end{array}$ & $\begin{array}{l}\text { prosedur } \\
\text { tidak Up to } \\
\text { Date }\end{array}$ & $\begin{array}{l}\text { Sea Water } \\
\text { Supply } \\
\text { Bermasalah }\end{array}$ & 2 & 2 & 2 & 8 \\
\hline & & & $\begin{array}{l}\text { Prosedur } \\
\text { tidak sesuai }\end{array}$ & $\begin{array}{l}\text { prosedur } \\
\text { tidak } \\
\text { terperinci } \\
\text { secara jelas }\end{array}$ & $\begin{array}{l}\text { Sea Water } \\
\text { Supply } \\
\text { Bermasalah }\end{array}$ & 2 & 2 & 2 & 8 \\
\hline
\end{tabular}




\begin{tabular}{|c|c|c|c|c|c|c|c|c|}
\hline \multirow{4}{*}{14} & \multirow{4}{*}{$\begin{array}{c}\text { Machine } \\
\text { Tool }\end{array}$} & PLC failure & card rusak & $\begin{array}{l}\text { Sea Water } \\
\text { Supply } \\
\text { Bermasalah }\end{array}$ & 5 & 2 & 1 & 10 \\
\hline & & $\begin{array}{l}\text { Pompa sea } \\
\text { water } \\
\text { abnormal }\end{array}$ & $\begin{array}{c}\text { pompa } \\
\text { ngempos }\end{array}$ & $\begin{array}{l}\text { Sea Water } \\
\text { Supply } \\
\text { Bermasalah }\end{array}$ & 5 & 1 & 1 & 5 \\
\hline & & $\begin{array}{c}\text { Breaker } \\
\text { pompa sea } \\
\text { water rusak }\end{array}$ & $\begin{array}{l}\text { breaker } \\
\text { terbakar }\end{array}$ & $\begin{array}{c}\text { Sea Water } \\
\text { Supply } \\
\text { Bermasalah }\end{array}$ & 5 & 1 & 1 & 5 \\
\hline & & $\begin{array}{l}\text { Control } \\
\text { valve } \\
\text { abnormal }\end{array}$ & $\begin{array}{l}\text { booster crv } \\
\text { kotor }\end{array}$ & $\begin{array}{l}\text { Sea Water } \\
\text { Supply } \\
\text { Bermasalah }\end{array}$ & 4 & 2 & 1 & 8 \\
\hline \multirow{4}{*}{15} & \multirow{4}{*}{ Material } & $\begin{array}{c}\text { Pompa sea } \\
\text { water trip }\end{array}$ & $\begin{array}{c}\text { arus motor } \\
\text { melebihi } \\
\text { setting } \\
\text { proteksi }\end{array}$ & $\begin{array}{l}\text { Sea Water } \\
\text { Supply } \\
\text { Bermasalah }\end{array}$ & 5 & 3 & 1 & 15 \\
\hline & & $\begin{array}{l}\text { Gasket line } \\
\text { sea water } \\
\text { getas }\end{array}$ & aging & $\begin{array}{l}\text { Sea Water } \\
\text { Supply } \\
\text { Bermasalah }\end{array}$ & 4 & 2 & 1 & 8 \\
\hline & & $\begin{array}{c}\text { Strainer } \\
\text { buntu }\end{array}$ & $\begin{array}{l}\text { banyak } \\
\text { sampah }\end{array}$ & $\begin{array}{l}\text { Sea Water } \\
\text { Supply } \\
\text { Bermasalah }\end{array}$ & 4 & 4 & 1 & 16 \\
\hline & & $\begin{array}{c}\text { Flange } \\
\text { /koneksi line } \\
\text { sea water } \\
\text { bocor }\end{array}$ & $\begin{array}{l}\text { seal getas / } \\
\text { flange pipa } \\
\text { retak }\end{array}$ & $\begin{array}{l}\text { Sea Water } \\
\text { Supply } \\
\text { Bermasalah }\end{array}$ & 4 & 2 & 1 & 8 \\
\hline
\end{tabular}

\section{ANALISIS DAN INTERPRETASI}

\subsection{Hasil Perhitungan RPN}

Hasil pengolahan dengan metode FMEA pada tabel 4.6 diketahui bahwa potensi mode kegagalan tertinggi pada masing-masing sub equipment dapat dilihat pada tabel di bawah ini :

Tabel 5.1 Risk Priority Number Tertinggi Kegagalan Operasi Chlorination Plant

\begin{tabular}{|c|c|c|c|c|}
\hline No. & $\begin{array}{c}\text { Sub } \\
\text { Equipment }\end{array}$ & Category & Failure Mode & RPN \\
\hline 1 & Rectifier & Material & $\begin{array}{c}\text { SCR Resistansi } \\
\text { Rendah }\end{array}$ & 15 \\
\hline 2 & Cell Chlorine & Material & Cell Bocor & 32 \\
\hline 3 & $\begin{array}{c}\text { Sea Water } \\
\text { Supply }\end{array}$ & Material & Strainer Buntu & 16 \\
\hline
\end{tabular}

Sedangkan bila ditinjau dari tabel 4.3 sebagai dasar pembuatan pie diagram, persentase jumlah WO tertinggi yang terdapat dalam MIM'S ELLIPSE untuk periode 2001 - 2018 adalah sebagai berikut : 


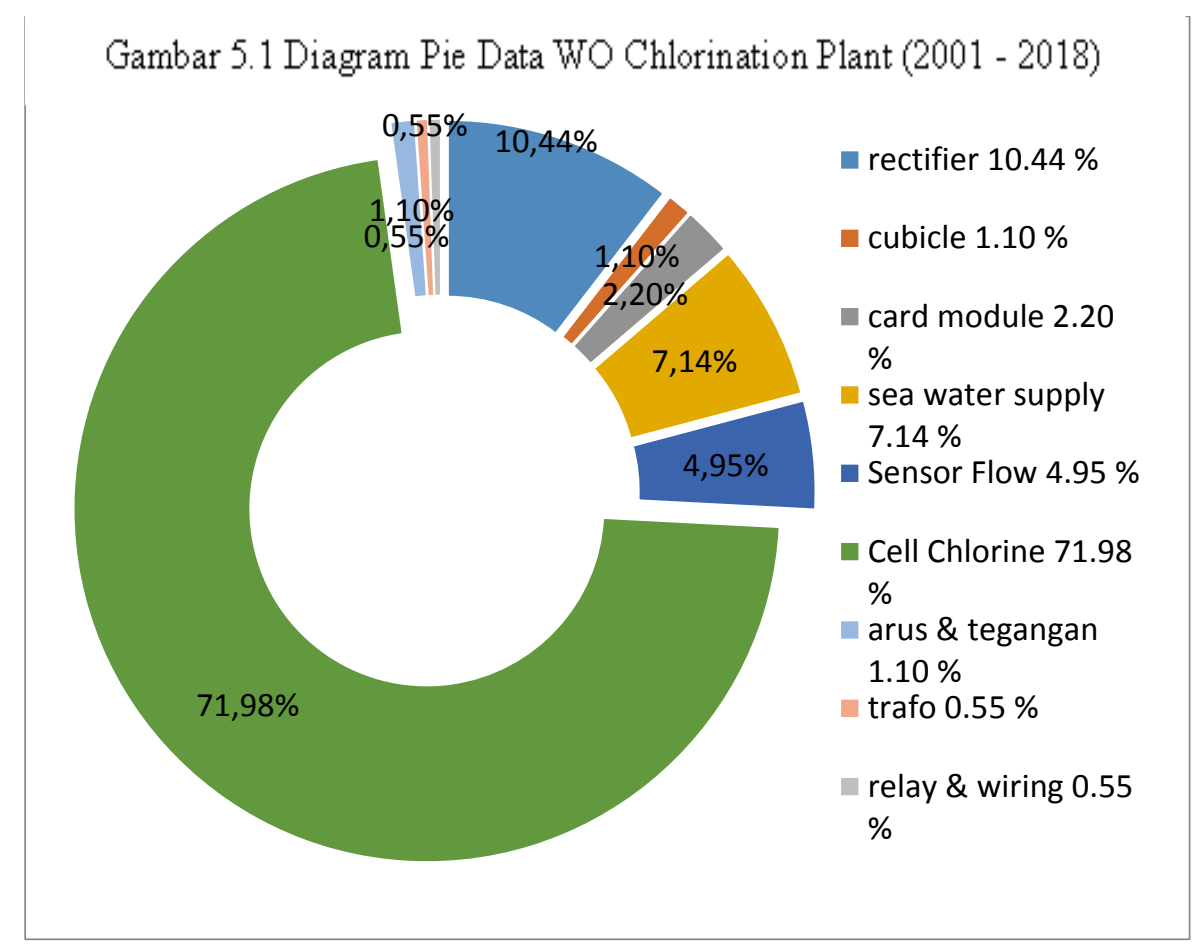

\subsection{Analisis Menggunakan Metode Fault Tree Analysis}

Langkah - langkah FTA :

Langkah 1. Menentukan tujuan yang ingin dicapai dari FTA. Tujuan pembuatan fault tree analysis.

Langkah 2. Mendefinisikan top event. Setelahnya dimulai membuat struktur dari fault tree.

Langkah 3. Mendefinisikan batasan, cakupan dari sistem dengan memperhatikan aturan dari FTA.

Langkah 4. Memulai membuat fault tree. Sehingga tersusunlan gerbang logika sebagai wujud analisis penyebab kegagalan. 


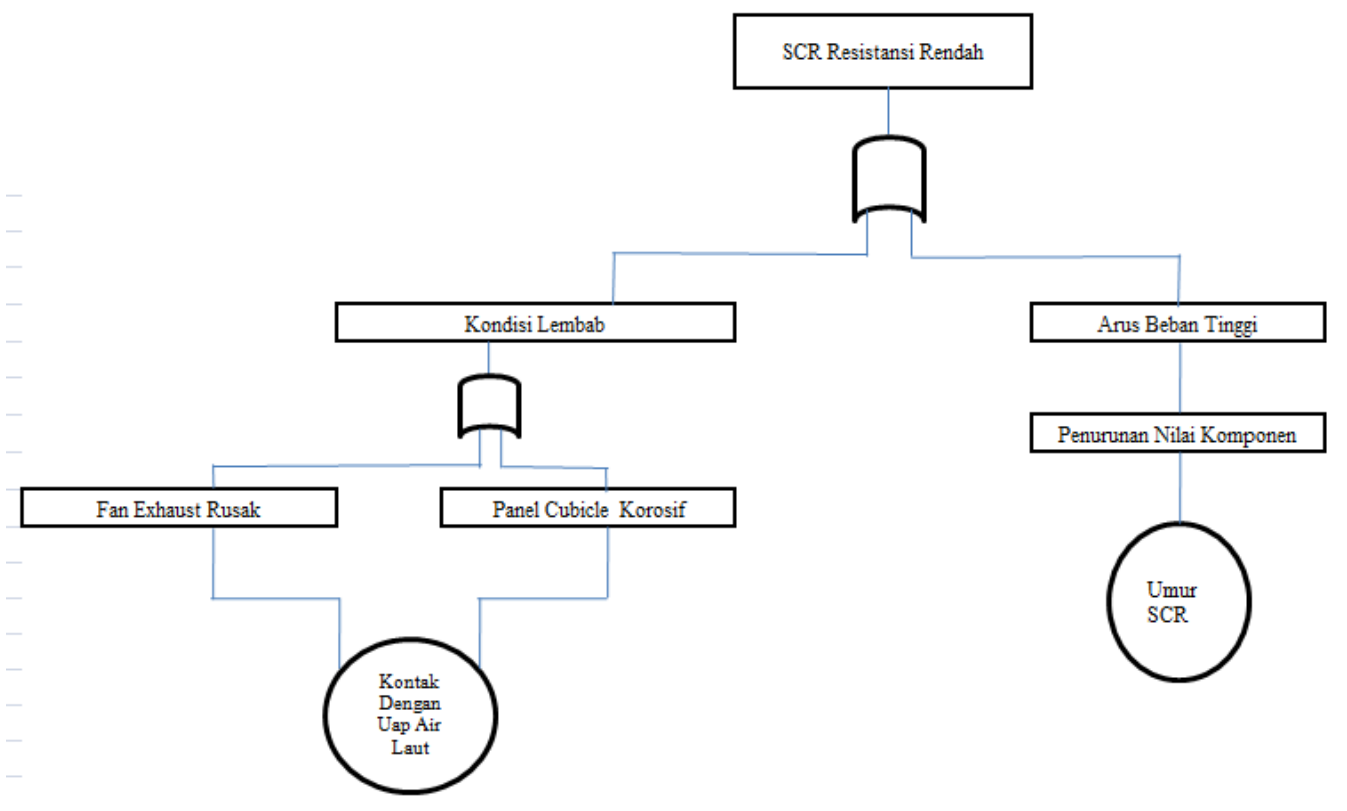

Gambar 5.4 FTA Rectifier

Dari gambar 5.5 didapatkan persamaan Booleannya :

$\mathrm{T}=\mathrm{G} 1+\mathrm{G} 2$

$\mathrm{G} 1=\mathrm{G} 3+\mathrm{G} 4$

$\mathrm{G} 2=\mathrm{G} 5$

$\mathrm{G} 3=\mathrm{P} 1$

$\mathrm{G} 5=\mathrm{P} 2$

$\mathrm{G} 4=\mathrm{P} 1$

Dari persamaan di atas disubstitusi menjadi :

$\mathrm{T}=\mathrm{P} 1+\mathrm{P} 2$

Maka minimal cut set dari gambar adalah $=\{\mathrm{P} 1\},\{\mathrm{P} 2\}$

Diterjemahkan dalam analisis kualitatif yaitu : kegagalan chlorination plant yang diakibatkan rectifier terjadi dikarenakan:

- Kontak dengan air laut

- $\quad$ Umur SCR 


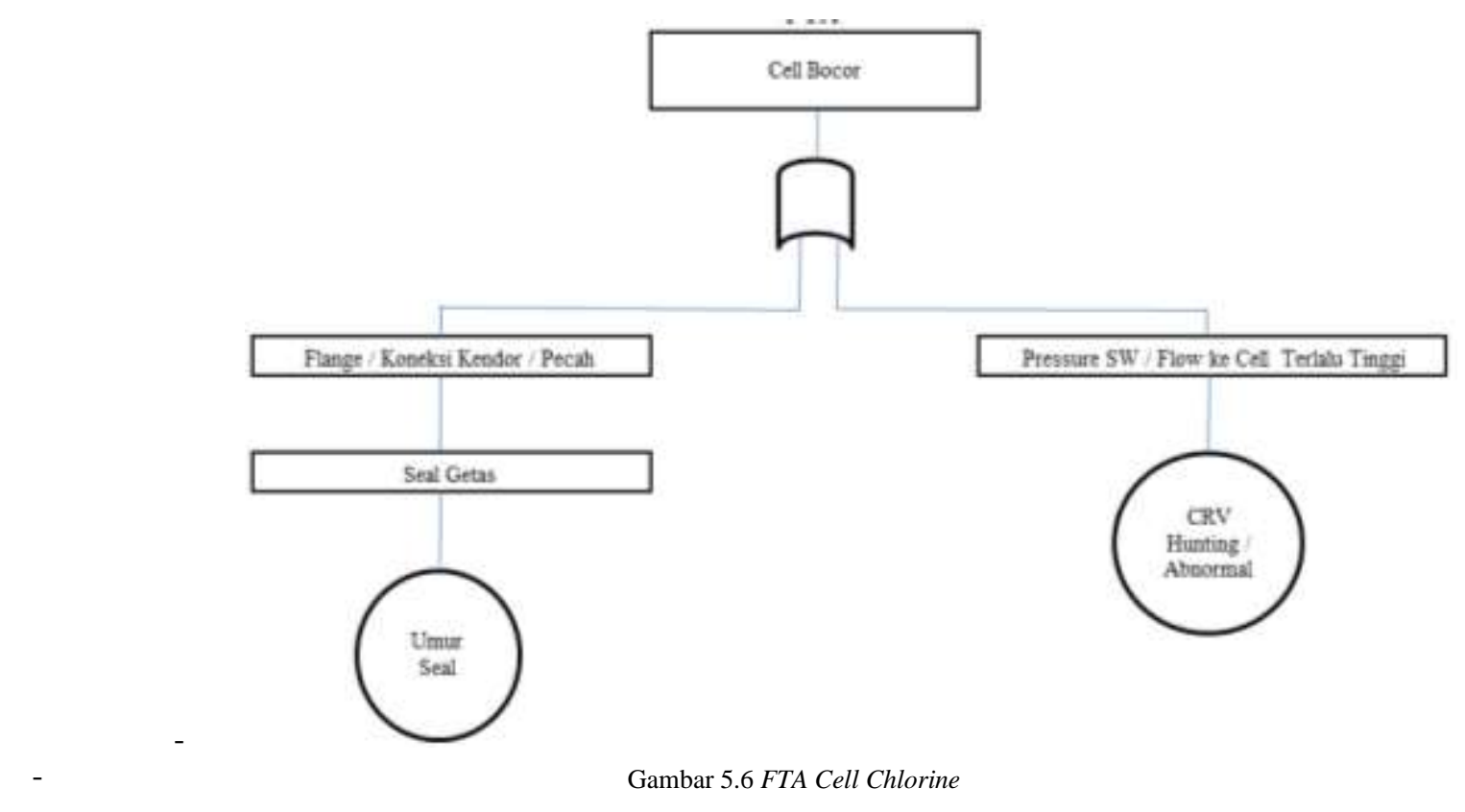

Dari gambar 5.7 didapatkan persamaan Booleannya :

$\mathrm{T}=\mathrm{G} 1+\mathrm{G} 2$

$\mathrm{G} 1=\mathrm{G} 3 \quad \mathrm{G} 2=\mathrm{P} 2$

$\mathrm{G} 3=\mathrm{P} 1$

Dari persamaan di atas disubstitusi menjadi :

$\mathrm{T}=\mathrm{P} 1+\mathrm{P} 2$

Maka minimal cut set dari gambar adalah $=\{\mathrm{P} 1\},\{\mathrm{P} 2\}$

Diterjemahkan dalam analisis kualitatif yaitu : kegagalan chlorination plant yang diakibatkan cell chlorine terjadi dikarenakan:

- Umur seal

- CRV Hunting / abnormal 


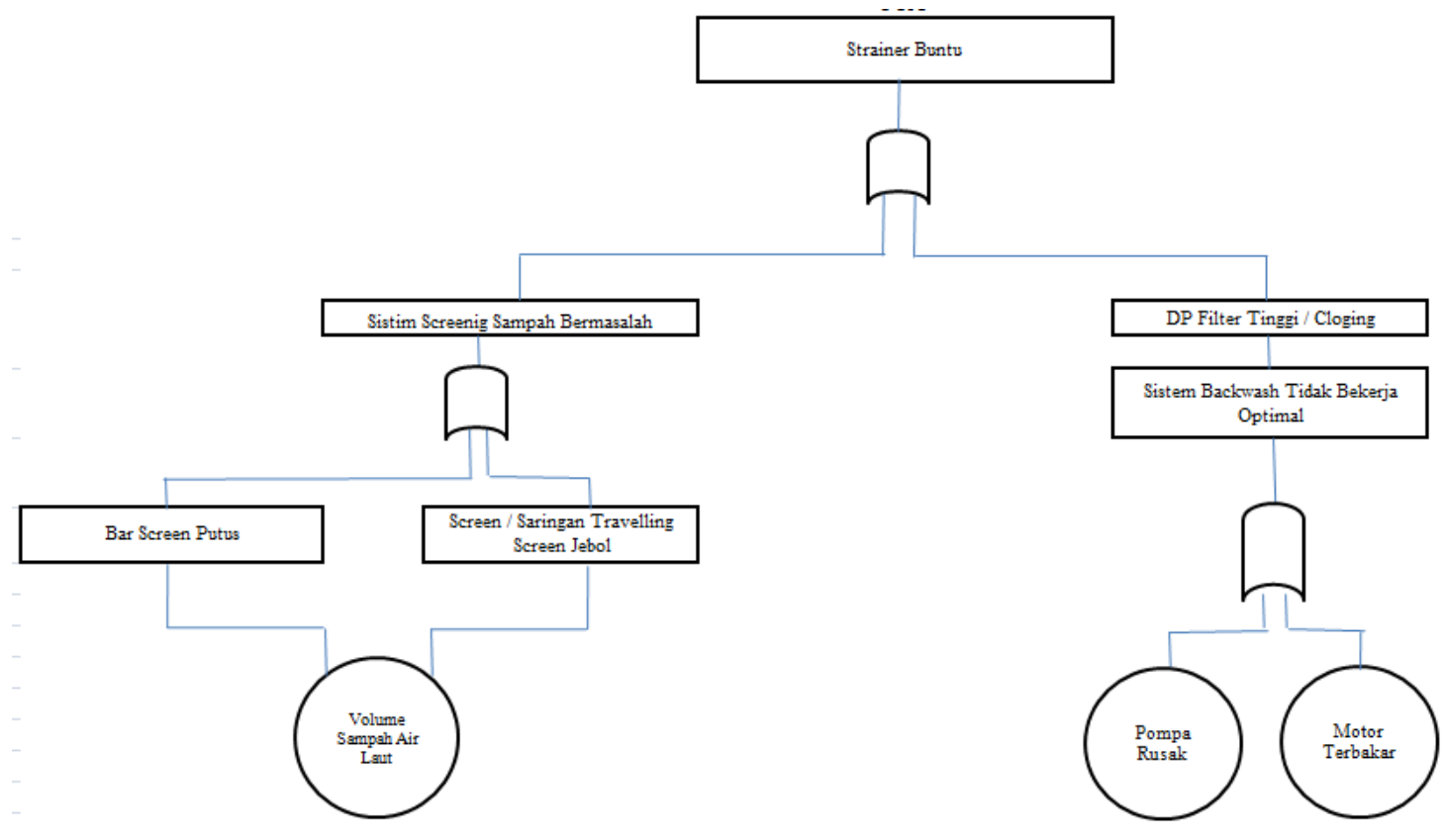

Gambar 5.8 FTA Sea Water Supply

Dari gambar 5.9 didapatkan persamaan Booleannya :

$\mathrm{T}=\mathrm{G} 1+\mathrm{G} 2$

$\mathrm{G} 1=\mathrm{G} 3+\mathrm{G} 4$

$\mathrm{G} 2=\mathrm{G} 5$

$\mathrm{G} 3 / \mathrm{G} 4=\mathrm{P} 1$

$\mathrm{G} 5=\mathrm{P} 2+\mathrm{P} 3$

Dari persamaan di atas disubstitusi menjadi :

$\mathrm{T}=\mathrm{P} 1+\mathrm{P} 2+\mathrm{P} 3$

Maka minimal cut set dari gambar adalah $=\{\mathrm{P} 1\},\{\mathrm{P} 2\},\{\mathrm{P} 3\}$

Diterjemahkan dalam analisis kualitatif yaitu : kegagalan chlorination plant yang diakibatkan sea water supply terjadi dikarenakan:

- Volume Sampah Air Laut

- $\quad$ Pompa Rusak

- $\quad$ Motor Terbakar

\subsection{Usulan Solusi (Failure Defense Task / FDT)}

Failure Defense Task (FDT) adalah sebuah prosedur pencegahan (preventive) pemeliharaan untuk menghindari terjadinya suatu kejadian mode kegagalan. Berikut adalah FDT dari hasil FTA Kegagalan Chlorination Plant :

Tabel 5.2 Usulan Solusi Untuk Kegagalan Chlorination Plant

\begin{tabular}{|c|c|c|c|}
\hline No. & Failure Mode & Failure Cause & \multicolumn{1}{c|}{$\begin{array}{c}\text { Failure } \\
\text { Defense Task } \\
\text { (FDT) }\end{array}$} \\
\hline 1 & $\begin{array}{c}\text { Rectifier SCR } \\
\text { Resistansi } \\
\text { Rendah }\end{array}$ & Kontak dengan uap air laut & $\begin{array}{l}\text { Melakukan pemeliharaan } \\
\text { preventive koondisi fan exhaust } \\
\text { building plant dan fan exhaust panel } \\
\text { cubicle sebulan sekali }\end{array}$ \\
\hline
\end{tabular}




\begin{tabular}{|c|c|c|c|}
\hline & & & $\begin{array}{l}\text { Melakukan pengecekan kondisi } \\
\text { kebersihan panel dan seal pintu pintu } \\
\text { panel cubicle } \\
\text { - } \quad \text { Mengkondisikan pintu ruang } \\
\text { panel rectifier selalu tertutup (normally } \\
\text { closed) } \\
\text { - Menghindari uap air laut dan uap } \\
\text { gas bocoran cell generator }\end{array}$ \\
\hline & & Umur SCR & $\begin{array}{l}\text { - Melakukan pengukuran nilai } \\
\text { SCR saat chlorine tidak beroperasi dan } \\
\text { membuat database atau trending histori } \\
\text { hasil pengukuran } \\
\text { - Melakukan cleaning preventive } \\
\text { permukaan heat sink dan cleaning SCR } \\
\text { sebulan sekali } \\
\text { - Membuat rekomendasi } \\
\text { pembatasan pembebanan SCR apabila } \\
\text { ada penurunan nilai hasil pengukuran } \\
\text { sambil menunggu prosses pengadaan } \\
\text { untuk penggantian SCR baru }\end{array}$ \\
\hline \multirow{2}{*}{2} & \multirow{2}{*}{$\begin{array}{c}\text { Cell Chlorine } \\
\text { Bocor }\end{array}$} & Umur Seal & $\begin{array}{l}\text { - } \quad \text { Melakukan pengecekan rutin } \\
\text { kondisi kekencangan koneksi cell dan } \\
\text { kondisi fisik seal } \\
-\quad \text { Cleaning rutin cell chlorine } 1 \\
\text { minggu sekali } \\
-\quad \text { Melakukan penggantian seal } \\
\text { koneksi yang sudah getas saat chlorine } \\
\text { tidak beroperasi }\end{array}$ \\
\hline & & CRV Hunting/ Abnormal & $\begin{array}{l}\text { - } \\
\text { setiap } 1 \text { bulan sekali , saat chlorine tidak } \\
\text { beroperasi } \\
\text { - } \quad \text { Melakukan greasing /pelumasan } \\
\text { pada stem CRV } \\
\text { - } \quad \text { Membuat rekomendasi } \\
\text { penggantian CRV berdasarkan standart } \\
\text { life time fabrikan } \pm 15 \text { tahun }\end{array}$ \\
\hline 3 & $\begin{array}{c}\text { Sea Water } \\
\text { Supply Strainer } \\
\text { Buntu }\end{array}$ & Volume sampah air laut & $\begin{array}{l}\text { - } \quad \text { Melakukan pengecekan rutin } \\
\text { kondisi barscreen setiap } 1 \text { minggu sekali } \\
-\quad \text { Melakukan pengecekan rutin } \\
\text { kondisi ram traveling screen setiap } 1 \\
\text { minggu } \\
\text { - Melakukan pengecekan } \\
\text { kekencangan baut baut chain traveling } \\
\text { screen setiap } 1 \text { minggu }\end{array}$ \\
\hline
\end{tabular}




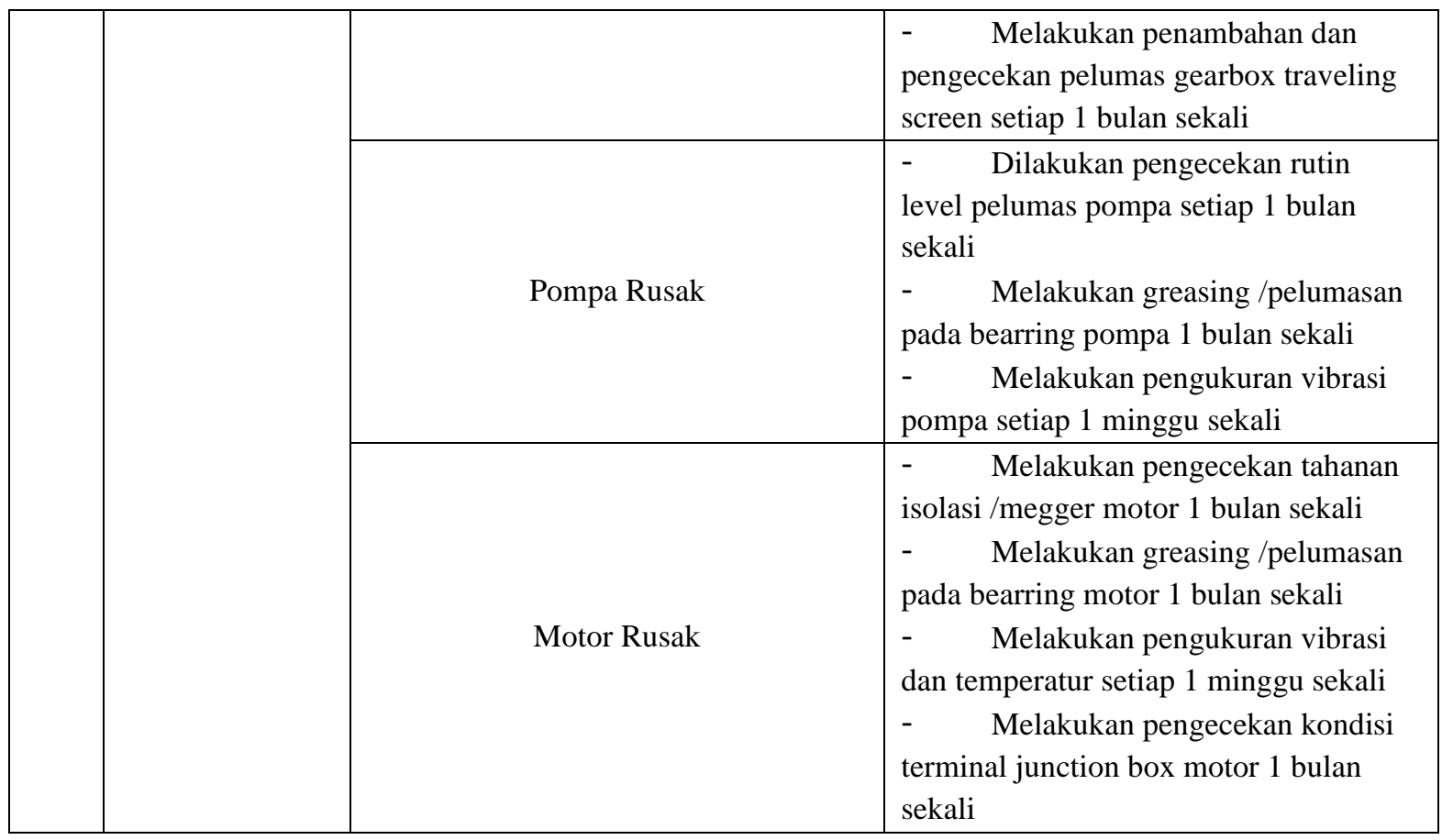

\section{PENUTUP}

\subsection{Kesimpulan}

Berdasarkan analisis dan evaluasi yang dilakukan dapat diperoleh beberapa kesimpulan sebagai berikut :

1. Penyebab kegagalan paling dominan pada Chlorination Plant yaitu :

- Pada sub equipment Rectifier, dengan mode kegagalan : SCR resistansi rendah.

- Pada sub equipment Cell chlorine, dengan mode kegagalan : bocor.

- Pada sub equipment Sea water Supply, dengan mode kegagalan : strainer buntu.

2. Berdasarkan hasil pengolahan data dengan metode FMEA bersama tim, dilanjutkan dengan analisis FTA, penyebab dasar dari kegagalan yang paling dominan pada Chlorination Plant yaitu:

- Kontak dengan uap air laut dan umur SCR untuk mode kegagalan SCR resistansi rendah.

- Umur seal dan CRV Hunting/ abnormal untuk mode kegagalan Cell Chlorine Bocor.

- Volume sampah air laut dan Pompa Rusak untuk mode kegagalan Strainer Buntu.

3. Usulan Pencegahan untuk meminimalkan terjadinya kegagalan pada Chlorination Plant yaitu

- Pada rectifier:
- Melakukan pemeliharaan preventive koondisi fan exhaust building plant dan fan exhaust panel cubicle sebulan sekali,

- Melakukan pengecekan kondisi kebersihan panel dan seal pintu pintu panel cubicle,

- Mengkondisikan pintu ruang panel rectifier selalu tertutup (normally closed),

- Menghindari uap air laut dan uap gas bocoran cell generator, pengukuran nilai SCR saat chlorine tidak beroperasi dan membuat database atau trending histori hasil pengukuran, cleaning preventive permukaan heat sink dan cleaning SCR sebulan sekali,

- Membuat rekomendasi pembatasan pembebanan SCR apabila ada penurunan nilai hasil pengukuran sambil menunggu prosses pengadaan untuk penggantian SCR baru.

- Pada cell chlorine :

- Melakukan pengecekan rutin kondisi kekencangan koneksi cell dan kondisi fisik seal,

- Cleaning rutin cell chlorine 1 minggu sekali,

- Melakukan penggantian seal koneksi yang sudah getas saat chlorine tidak beroperasi,

- Dilakukan loop test open closed setiap 1 bulan sekali, saat chlorine tidak beroperasi,

- Melakukan greasing /pelumasan pada stem CRV, 
- Membuat rekomendasi penggantian CRV berdasarkan standart life time fabrikan \pm 15 tahun.

- Pada sea water supply:

- Melakukan pengecekan rutin kondisi barscreen, ram traveling screen dan baut baut chain traveling screen setiap 1 minggu,

- Melakukan penambahan dan pengecekan pelumas gearbox traveling screen setiap 1 bulan sekali,

- Melakukan pengecekan tahanan isolasi /megger motor 1 bulan sekali,

- Melakukan greasing /pelumasan pada bearring motor 1 bulan sekali,

- Melakukan pengukuran vibrasi dan temperatur setiap 1 minggu sekali,

\section{DAFTAR PUSTAKA}

Bakhtiar, Arfan; Diana Puspitasari; Diah Ayu Wulandari. 2016, Analisa Kegagalan Proses Pengolahan Produk Piring Menggunakan Metode Failure Modes, Effect and Analysis dan Fault Tree Analysis di PT. Sango Ceramics Indonesia, Universitas Diponegoro, Semarang.

https://www.neliti.com/id/publications/189524/ana lisa-kegagalan-proses-pengolahan-produkpiring-menggunakan-metode-failure-mod https://ejournal3.undip.ac.id/index.php/ieoj/article/ view/11910, Home > Vol 5, No 2 (2016) > Wulandari

Gunawan, Indra :. 2017, Analisa Kegagalan Proses Regenerasi Water Treatment Plant \#2 PLTGU Unit Pembangkitan Gresik Dengan Metode FMEA dan FTA, Universitas Muhammadiyah, Gresik.

Hidayat, Imam; Swandya Eka Pratiwi. 2013, Analisa Factor Penyebab Kegagalan Mesin Grinder Pada Proses Produksi Plastik Film di PT. Mutiara Hexagon, Universitas Mercu Buana, Jakarta.
- Melakukan pengecekan kondisi terminal junction box motor 1 bulan sekali.

\subsection{Saran}

Adapun saran-saran dari penulis demi meningkatkan penelitian dan performansi bisnis bagi perusahaan adalah sebagai berikut:

1. Untuk menurunkan resiko kegagalan selanjutnya disarankan untuk mereview standart job prediktif maintenance pada peralatan tersebut.

2. Memetakan remaining useful life peralatan Chlorination Plant agar pasokan $\mathrm{NaOCl}$ tetap terjaga, sehingga tidak mengganggu kinerja peralatan utama pembangkit listrik.

Lestari, Ning Puji; Siti Syamsiah; Sarto; Wiratni Budhijanto 2016, Evaluasi Kehandalan Reaktor Biogas Skala Rumah tangga di Daerah Istimewa Yogyakarta dengan Metode Analisi Fault Tree, Universitas Gajah Mada, Yogyakarta.

Purba, H.H. (2008, September 25). Diagram fishbone dari Ishikawa. Retrieved from http://hardipurba.com/2008/09/25/diagramfishbone-dari-ishikawa.html

Surasa, Heru Agus. 2007, Analisis Penyebab Losses Energi Listrik Akibat Gangguan Jaringan Distribusi Menggunakan Metode Fault Tree Analysis dan Failure Mode and Effect Analysis di PT. PLN (PERSERO) UNIT PELAYANAN JARINGAN SUMBERLAWANG, Universitas Sebelas Maret, Surakarta.

Hidayat, H., Jufriyanto, M., \& Rizqi, A. (2020). ANALISIS OVERALL EQUIPMENT EFFECTIVENESS (OEE) PADA MESIN CNC CUTTING. ROTOR, 13(2), 61-66. doi:10.19184/rotor.v13i2.20674 